\title{
MODEL ANALYTICAL NETWORK PROCESS (ANP) DALAM PENGEMBANGAN PARIWISATA DI JEMBER
}

\author{
Sukidin \& Pudjo Suharso \\ Universitas Jember, Indonesia \\ Email: sukidin2005@yahoo.com
}

\begin{abstract}
Abstrak: Model Analytical Network Process (ANP) dalam Pengembangan Pariwisata di Jember. Penelitian ini mengkaji kebijakan pengembangan pariwisata di Jember, terutama kebijakan pengembangan agrowisata perkebunan kopi dengan menggunakan Jember Fashion Carnival (JFC) sebagai event marketing. Metode yang digunakan adalah soft system methodology dengan menggunakan metode analitis jaringan (Analytical Network Process). Penelitian ini menemukan bahwa pengembangan pariwisata di Jember masih dilakukan dengan menggunakan pendekatan konvensional, belum terkoordinasi dengan baik, dan lebih mengandalkan satu even (atraksi) pariwisata, yakni JFC, sebagai lokomotif daya tarik pariwisata Jember. Model pengembangan konvensional ini perlu dirancang kembali untuk memperoleh pariwisata Jember yang berkesinambungan.
\end{abstract}

Kata kunci: pergeseran paradigma, industry pariwisata, even pariwisata, agrowisata

\begin{abstract}
Analytical Network Process (ANP) Model in the Tourism Development in Jember. The purpose of this study is to conduct a review of the policy of tourism development in Jember, especially development policies for coffee plantation agrotourism by using Jember Fashion Carnival (JFC) as event marketing. The research method used is soft system methodology using Analytical Network Process. The result shows that the tourism development in Jember is done using a conventional approach, lack of coordination, and merely focus on a single event tourism, i.e. the JFC, as locomotive tourism attraction in Jember. This conventional development model needs to be redesigned to reach Jember sustainable tourism development.
\end{abstract}

Keywords: paradigm shift, tourism industry, agro-tourism

\section{PENDAHULUAN}

Seiring dengan terjadinya pergeseran paradigma pembangunan, dari paradigma pembangunan yang mengacu pada pertumbuhan (growth paradigm) ke arah paradigma pembangunan berkelanjutan (sustainable development paradigm), banyak negara sedang berkembang menjadikan industri pariwisata sebagai an alternative development option (Burns and Hoden, 1995; Nelson, 1993). Bahkan menurut Burns dan Holden, untuk beberapa negara yang tidak mempunyai sumber daya alam, kedua ahli manajemen pariwisata itu menyatakan not to have tourism is not an option. Selanjutnya Burns dan Holden (1995:95) menyatakan: Worldwide, tourism is looked upon as a smokeless industry with strong and stable economic impacts on host areas ... Tourism is viewed as the new wave of economic opportunity and is promoted heavily for this reason alone.

Pembangunan industri pariwisata di samping dinilai ramah lingkungan juga memberikan makna ekonomis yang signifikan bagi perkembangan perekonomian 
suatu negara. Di Indonesia makna ekonomis kehadiran industri pariwisata ditandai dengan sumbangan yang cukup signifikan dalam perolehan devisa, yang pada tahun 2010 mencapai hampir 15,23 miliar US \$. Di Kawasan Asia Pasifik perolehan devisa pariwisata Indonesia pada tahun 2010 menduduki urutan ke 7 setelah Hongkong, China, Thailand, Singapura, Australia dan Korea Selatan (Kementerian Pariwisata dan Kebudayaan, 2012). Mengingat pentingnya sector pariwisata maka pemerintah Indonesia kemudian menjadikan industri pariwisata sebagai "ideologi dominan"1 dalam reproduksi perekonomian baik pada tingkat nasional maupun daerah. Pada aras ide, ide disosialisasikan baik oleh pemerintah maupun korporasi swasta pariwisata tentang betapa pentingnya mengembangkan industri pariwisata. Masyarakat disosialisasi dengan idiom-idiom yang berhubungan dengan industri pariwisata seperti "Sapta Pesona Pariwisata", "Industri ramah lingkungan" dan sebagainya termasuk menciptakan sloganslogan modernism. Di Jember diciptakan idiom "Naturally Jember".

Industri pariwisata di Jember berkembang pesat setelah ada Jember Festival Carnaval (JFC) yang telah mendunia. JFC ini mampu memperkenalkan Jember kota kecil di pojok Jawa Timur - yang semula tidak dikenal, menjadi salah satu kiblat festival karnaval fashion yang kemudian mengilhami kota-kota lain di Indonesia untuk menirunya. JFC merupakan produk fashion Carnaval pertama di Indonesia. Jember yang

1 “ideoogi dominan" dimaksudkan sebagai pengejawantahan kebijakan pemerintah yang menempatkan pembangunan pariwisata sebagai ideologi(Arief Budiman, 1990:12). Triwikromo awalnya merupakan sebuah kota sebagai pengembangan industri perkebunan, dengan adanya JFC saat ini telah menjadi kota salah satu tujuan favorit wisatawan. Karnaval peragaan busana yang dilakukan pada catwalk sepanjang 3,6 kilometer ini setiap tahun pergelarannya selalu menarik perhatian masyarakat dan media, hal ini karena setiap busana yang dipamerkan selalu memberikan sentuhan estetika sehingga membentuk genre seni pertunjukan baru yang berbasis peragaan busana. Tidak dapat dipungkiri bahwa JFC saat ini telah mendunia, berbagai prestasi di kancah Internasional telah didapat. Akibat dari prestasi-prestasi yang diperoleh, JFC saat ini telah menjadi produk andalan wisata utama Kabupaten Jember. JFC telah berhasil menjadikan Jember sebagai kota wisata budaya dan membawa dampak yang besar bagi perekonomian Jember.

Data Kantor Pariwisata menunjukkan tren peningkatan kunjungan wisatawan dalam negeri, dari 741.279 orang pada 2012, meningkat menjadi 841.148 orang pada 2013, dan 882.826 pada 2014. Namun angka kunjungan wisatawan mancanegara meningkat tak terlalu tajam, yakni 1.018 orang pada 2012, meningkat menjadi 1.155 orang pada 2013, dan 1.212 orang pada 2014. Total wisatawan yang berkunjung ke Jember pada rentang 2012-2014 adalah 2.247.858 orang(Kabupaten Jember Dalam Angka, 2013)

Pada tahun 2008, PAD Kabupaten Jember dari sektor pariwisata hanya Rp 2,5 Miliar.

menyebutnya sebagai "budaya dominan" untuk memberikan penjelasan bagi kebijakan, ideologi ataupun cara-cara yang dipergunakan pemerintah dalam pembangunan. 
Namun tahun 2013 mampu menembus angka Rp 12 Miliar. Dari jumlah ini yang dihasilkan restoran atau wisata kuliner mencapai Rp1,2 miliar. Melalui wisata kreatif yang diwujudkan dalam JFC, APBD Jember meningkat mencapai Rp 3 triliun. Dalam sarana dan prasarana pariwisata, saat ini Jember sudah memiliki hotel berbintang tiga dengan jumlah kamar 500 - 600 kamar. Dan hotel melati sekitar 1.200 kamar. Semakin banyaknya tamu mendesak pengelola hotel untuk menambah jumlah kamar atau mendorong pertumbuhan hotel baru. Pasalnya, Tahun 2013 saja sebanyak 2.159 media dan fotografer dunia hadir di Jember. Tahun 2014, sudah 3.073 media dan fotografer yang mendaftar untuk hadir. JFC menjadi magnet pariwisata Jember yang sangat penting dan memberikan efek pengganda (multiplier effect) bagi perkembangan ekonomi Jember (Kantor Pariwisata Kabupaten Jember, 2014).

JFC dan daya tarik pariwisata Jember adalah dua sisi dalam satu mata uang. Namun menarik wisatawan hanya mengandalkan JFC di masa depan bukan tidak mungkin pariwisata Jember akan mengalami kemerosotan. Sebab banyak sekali daerah yang meniru festival semacam JFC. Di Sola terdapat Solo Batik Festival, di Yogyakarta ada Yogyakarta Classical Festival, di Jakarta terdapat Festival Budaya Jakarta, di Malang terdapat Batu Festival Carnaval, dan tetangga kota dekatnya, Banyuwangi juga telah mengadakan Banyuwangi Traditional Festival, yang kesemuanya berbasis pada fashion. Oleh karena itu apabila pengembangan pariwisata Jember tetap berbasis pada fashion maka pariwisata di Jember setidaknya akan menghadapi kompetitor potensial, Banyuwangi, yang saat ini tengah mengintensifkan bandaranya. Bandara Blimbingsari Banyuwangi telah memperpendek aksesibiltas dari Surabaya ke Banyuwangi, yang semula naik angkutan darat sekitar 6-7 jam dari Surabaya, maka dengan adanya bandara dan penerbangan langsung, Surabaya - Banyuwangi hanya ditempuh selama 40 menit. Dengan aksesibilitas yang makin mudah, wisatawan pertama-tama akan ke Banyuwangi dengan objek pantai dan alamnya, baru kemudian ke Jember. Itu pun kalau tidak langsung ke Bali.

Oleh karena itu dalam rangka pengembangan pariwisata di Jember, model pengembangan pariwisata yang lebih komprehensif, lengkap, perlu dikembangkan sebagai pariwisata alternative selain JFC karena Jember sebenarnya mempunyai banyak destinasi wisata yang layak dikembangkan baik wisata pantai, wisata pegunungan, atau wisata agro. Dalam pengembangan pariwisata Jember harus diperhatikan bahwa semua unsur penunjang pariwisata seperti perhotelan, biro perjalanan wisata, atraksi, sarpras, kebijakan, destinasi, dan sebagainya. Permasalahannya adalah sinergi antar pemangku kepentingan seperti pemerintah daerah Jember, Event Organizer, pihak perhotelan (PHRI), Biro perjalanan wisata, penyedia transportasi dan sebagainya belum membuat rancang bangun model pengembangan pariwisata alternative selain JFC untuk masa depan. Sampai saat ini kebijakan pengembangan pariwisata di Kabupaten Jember masih bertumpu pada fashion melalui JFC. Unsur-unsur penunjang pariwisata yang ada di Jember seperti PHRI, Biro Perjalanan Wisata, Event Organizer 
belum dioptimalkan perannya dalam menyusun kebijakan pengembangan pariwisata non fashion, yakni agrowisata perkebunan kopi yang justru menjadi sector pariwisata potensial.

Dalam perspektif teori pembangunan pariwisata, kebijakan pengembangan agrowisata merupakan manifestasi dari implementasi paradigm pariwisata berkelanjutan. Secara konseptual pariwisata berkelanjutan akan menyatukan kepentingan ekonomi, lingkungan dan sosial (Burn and Holden, 1995).

\section{METODE}

Penelitian ini menggunakan pendekatan Soft System Methodology dengan teknik proses analisis jaringan/Analytical Network Process (ANP) (Nugroho, 2013). Proses analisis jaringan (ANP) digunakan untuk menetapkan faktor-faktor yang menjadi prioritas dalam pengembangan model pariwisata di Jember. Penggunaan ANP ini memerlukan proses knowledge acquisition dilakukan untuk mendapatkan konsensus ahli di bidang pariwisata sebagai thinking respondents atau subject matters expert. Selain itu penelitian ini dibantu dengan metode FGD/sarasehan untuk mengidentifikasi komponen dan pengembangan pariwisata di Jember. Aktor yang dilibatkan dalam FGD antara lain Pemerintah Kabupaten Jember, PHRI, Biro Perjalanan Wisata, Agen Wisata, Event Organizer, LSM Pariwisata dan perwakilan masyarakat terutama yang berasal dari daerah tujuan wisata perkebunan kopi di Jember. Setelah mengetahui identifikasi komponen pariwisata dan identifikasi pengembangan pariwisata di Jember kemudian digunakan teknik ANP untuk pengambilan keputusan prioritas pariwisata yang akan dikembangkan.

\section{HASIL DAN PEMBAHASAN}

Jember merupakan daerah yang kaya akan keindahan alam serta budaya, dikelilingi oleh Pegunungan Argopuro dengan sejumlah air terjun di sebelah utara, perkebunan dan hutan lindung di sebelah timur dan barat, serta di sebelah selatan berbatasan langsung dengan lautan Indonesia. Perpaduan semuanya menyajikan pemandangan alam yang sangat indah serta nuansa petualangan yang sangat mempesona. Saat ini Kabupaten Jember setidaknya mempunyai 24 destinasi pariwisata, yang dapat dikunjungi dan dinikmati setiap saat. Tidak seperti ketika diadakan perhelatan JFC pada setiap bulan Agustus, destinasi pariwisata lain di Jember dapat dikunjungi setiap hari. Untuk mengetahui destinasi pariwisata di Jember, dapat disimak pada Peta Pariwisata Jember pada Gambar 1, 2 dan 3.

Pengembangan kepariwisataan di Jember memanfaatkan keberadaan JFC sebagai event marketing dalam rangka meningkatkan brand awareness kepariwisataan di Jember. Ada beberapa aktor kepariwisataan yang terlibat atau dilibatkan oleh Pemerintah Kabupaten Jember untuk memasarkan pariwisata Jember melalui JFC. Yakni, media massa, Manajemen JFC, PHRI, Biro Perjalanan, dan Penyedia kuliner. Masing-masing pihak ini mempunyai jaringan sendiri-sendiri untuk memasarkan pariwisata Jember melalui JFC. Kerjasama antar jaringan inilah yang membuat Jember melalui JFC menjadi terkenal dan menjadi salah satu destinasi pariwisata menarik di Jawa Timur selain 


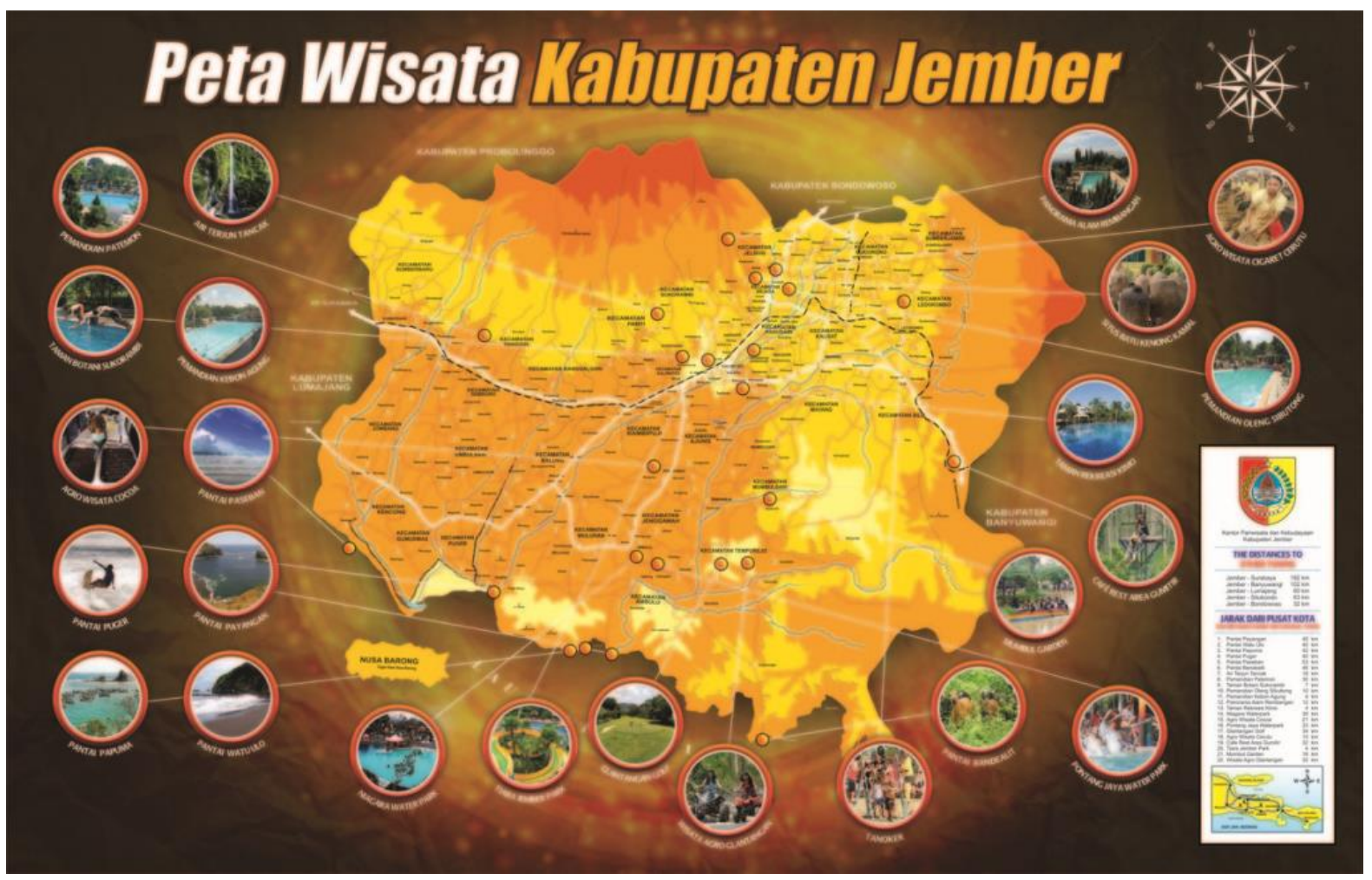

Gambar 1. Peta Pariwisata Kabupaten Jember

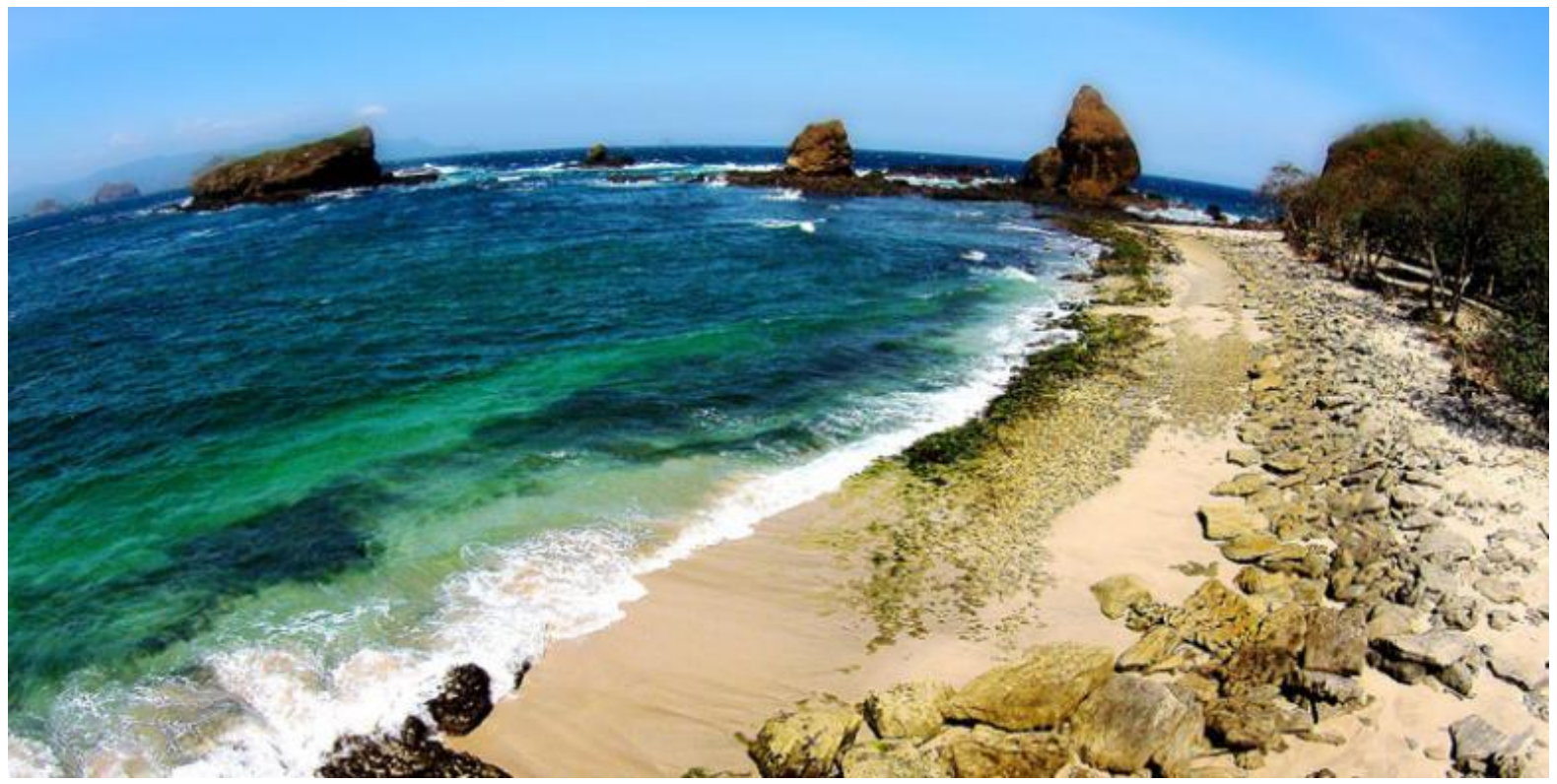

Gambar 2. Pantai Papuma : Eksotik, salah satu keindahan di Jember.

Bromo, Kawah Ijen, dan Kawasan Hutan Merubetiri.

Pada saat diadakan perhelatan JFC yang dihadiri oleh para ahli dan penikmat pariwisata, Pemerintah Kabupaten Jember melakukan sarasehan/FGD untuk meminta pendapat para ahli dan penikmat wisata yang menghadiri JFC dalam pengembangan kepariwisataan di Jember. Sebagian para ahli dan media massa yang terlibat dalam sarasehan atau FGD memang sengaja diundang oleh Pemerintah Kabupaten 


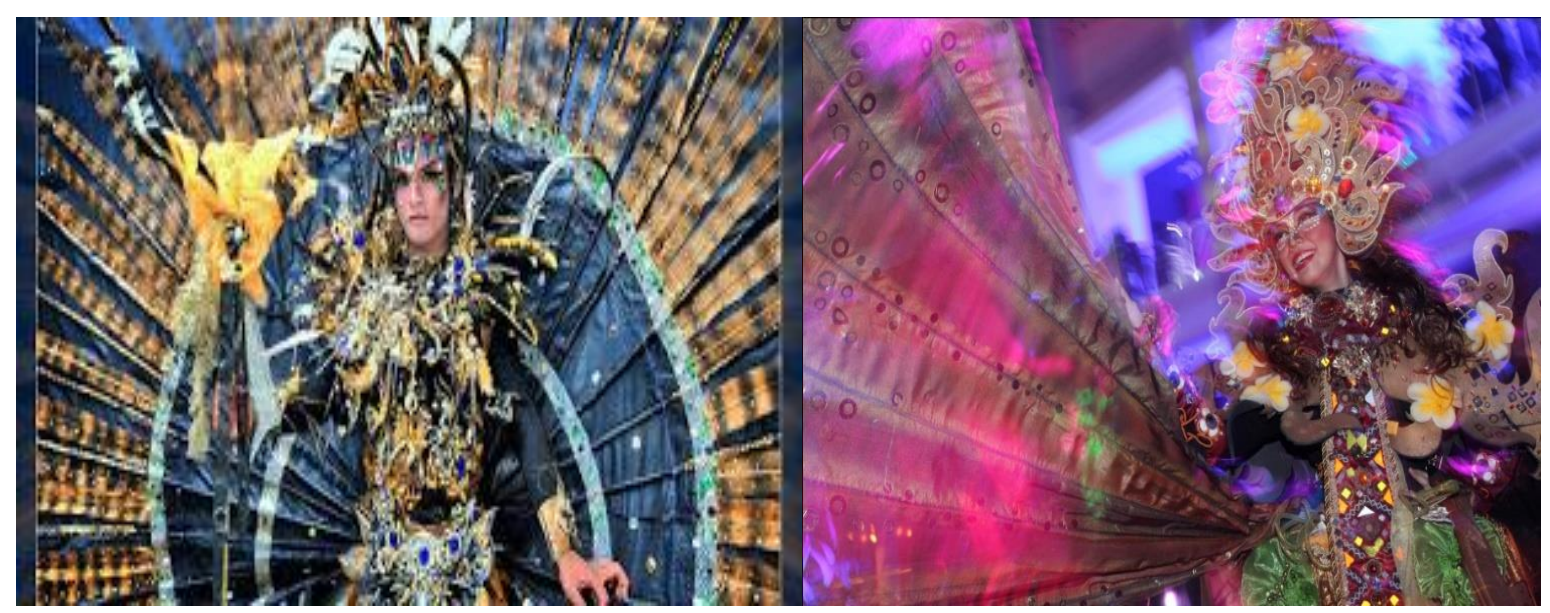

Gambar 3. Salah satu kostum/fashion JFC

Jember agar memberikan sumbang saran dan pemikiran dalam pengembangan pariwisata di Jember.

Dalam sarasehan atau FGD diperoleh hasil pengembangan pariwisata di Jember yang mencakup factor pendukung dan jenis pariwisata yang menjadi prioritas dikembangkan di masa mendatang selain JFC. Melalui analisis berjenjang diperoleh hasil penelitian sebagai berikut.

\section{IDENTIFIKASI FAKTOR PENGEMBANGAN}

\section{PARIWISATA DI JEMBER: APA YANG}

\section{DIPERLUKAN.}

Untuk mengidentifikasi faktor pengembangan pariwisata di Jember dilakukan dengan menggunakan teknik analisis Delphi yang melibatkan peserta sarasehan/FGD yang diterapkan dalam analisa stake holder sebelumnya. Para peserta sarasehan atau FGD mengeluarkan pendapat mengenai kesetujuan atau ketidaksetujuan mereka terhadap kebutuhan faktor pengembangan yang telah dirumuskan untuk pengembangan pariwisata yang terintegrasi dengan JFC di Kabupaten Jember. Artinya, setelah menikmati JFC, para wisatawan yang datang ke Jember, terutama yang berasal dari luar Jember, khususnya dari mancanegara,tidak dibiarkan terus pulang, tetapi dikoordinasi oleh Pemerintah Kabupaten Jember dan bekerjasama dengan Biro Perjalanan Wisata serta PHRI, para wisatawan ini diajak "tour de Jember", menjelajah tempat-tempat wisata di Jember yang jumlahnya cukup banyak, baik di pantai, pegunungan, perkebunan, atau situs-situs budaya Jember.

Hasil eksplorasi dari beberapa sarasehan dan FGB diperoleh pendapat dari para ahli dan pemerhati pariwisata Jember mengenai kebutuhan faktor pengembangan pariwisata di Kabupaten Jember.

1. Pembentuk daya tarik wisata Semua pihak setuju bahwa daya tarik wisata suatu kawasan yang terkait dengan keberadaan serta kondisi dari sumberdaya alam dan sumberdaya budaya untuk diadakan. Kebanyakan peserta sarasehan/FGD yang diadakan oleh Pemerintah Kabupaten Jember memiliki pemahaman yang sama bahwa daya tarik wisata merupakan sebuah poin penting yang harus dimiliki oleh setiap kawasan wisata agar dapat menarik minat para wisatawan untuk 
mengunjungi kawasan wisata di Kabupaten Jember. Di sini pengembangan daya tarik pariwisata Jember belum semenarik penyelenggaraan JFC, sehingga banyak yang dating ke Jember hanya menyaksikan JFC. Ini berimplikasi pada lama tinggal (length of stay) wisatawan yang pendek di Jember. Rata-rata para penikmat wisata mempunyai lama tinggal di Jember hanya1,6 hari. Artinya, malam dating, nginap di hotel, besok sudah meninggalkan Jember.

2. Ketersediaan prasarana wisata Seluruh peserta sarasehan dan FGD menyatakan setuju bahwa ketersediaan prasarana dalam suatu kawasan perlu dijadikan sebagai faktor pengembangan kawasan wisata di Kabupaten Jember. Alasan yang diungkapkan cukup memperlihatkan bahwa kondisi prasarana wisata di Kabupaten Jember tidak layak bahkan tidak semua kawasan wisata terfasilitasi dengan prasarana yang cukup. Faktor aksesbilitas ke tempat-tempat tujuan pariwisata di Jember menjadi kendala utama bagi pengembangan pariwisata di Jember saat ini.

3. Ketersediaan sarana wisata

Ketersediaan sarana wisata di sini berkaitan dengan adanya fasilitas penunjang dan fasilitas pendukung seperti akomodasi, aksesibilitas dan galeri-galeri yang berisikan ciri khas dari masing-masing kawasan wisata. Dari sarasehan/FGD terungkap kesetujuannya mengenai ketersediaan sarana tersebut. Selain dapat mempermudah akses para wisatawan dengan tersedianya transportasi umum, dikarenakan juga akses transportasi menuju ke kawasan wisata di Kabupaten Jember yang menggunakan kendaraan pribadi. Untuk akomodasi seperti penginapan dan rumah makan tidak semua tempat wisata memilikinya. Transportasi public berupa taksi memang ada, namun dinilai kurang layak dan seringkali para wisatawan dikenai harga sewa yang tinggi, belum terstandar dengan baik

4. Partisipasi masyarakat

Dalam sarasehan atau FGD dinyatakan perlunya partisipasi masyarakat yang mendukung kegiatan wisata di kawasan wisata Jember. Masyarakat harus mempunyai "sense of tourism" (Holden, 1995). Hal ini akan menuntun masyarakat menjadi "ramah" terhadap wisatawan yang dating di Jember. Para peserta sarasehan/FGD menjelaskan bahwa partisipasi masyarakat sangat menguntungkan baik untuk pengelola, pengunjung, pemerintah hingga kepada masyarakatnya sendiri. Dengan bergabungnya masyarakat ke dalam kegiatan wisata tersebut, masyarakat juga akan mendapatkan penghasilan dari kebudayaan lokal yang ada di kawasan wisata yang bisa ditunjukkan oleh masyarakat sekitar kawasan. Bisa dengan mempertunjukkan adat istiadat seharihari di daerah masing-masing.

5. Kelembagaan

Dalam sarasehan? FGD tidak semua peserta setuju dengan adanya peran serta suatu lembaga sebagai faktor pengembangan kawasan wisata di Kabupaten Jember. Beberapa peserta FGD yang menyatakan tidak setuju 
menjelaskan bahwa sebaiknya untuk peningkatan, pengelolaan dan pengembangan di kawasan wisata cukup dipegang dan dikendalikan oleh satu badan pengelola saja. Di sisi lain, peserta lain yang setuju menyatakan bahwa peran serta suatu lembaga sangat dibutuhkan dalam pengembangan pariwisata di Jember.

6. Kesempatan investasi

Seluruh peserta FGD/sarasehan menyatakan setuju bahwa diperlukan adanya kesempatan investasi para investor yang ingin mengembangkan kawasan wisata di Kabupaten Jember. Selain dapat menunjang pengembangan dan pengelolaan kawasan wisata, segala kendala dalam pembiayaan juga dengan mudah dapat teratasi dalam pengembangannya.

\section{Kebijakan}

Kebijakan yang dimaksud di sini yaitu peraturan dari pemerintah daerah yang mendukung pengembangan kawasan wisata di Kabupaten Jember. Semua peserta sarasehan/FGD menyatakan setuju dengan adanya kebijakan dari pemerintah terkait pengembangan kawasan wisata.

8. Pemasaran

Dalam sarasehan/FGD terungkap bahwa para ahli dan pemerhati pariwisata Jember setuju dengan adanya pemasaran yang digunakan sebagai faktor pengembangan. $\mathrm{Hal}$ ini dikarenakan pemasaran yang ada saat ini hanya diprioritaskan kepada satu kawasan wisata bahari saja sehingga tidak adanya pemerataan dalam hal pemasaran. Para peserta sarasehan atau
FGD mengatakan bahwa event JFC dapat dijadikan ajang pemasaran pariwisata di Jember yang efektif.

\section{ANALISIS PROSES JARINGAN PENGEMBANGAN PARIWISATA JEMBER}

Dalam tahap berikutnya analisis faktor kebutuhan pengembangan pariwisata digunakan analisis proses jaringan atau analytical network process. Hasilnya dapat dilihat pada tiga aras pengembangan pariwisata di Jember. Pertama, pada aras strategic pengembangan pariwisata di Jember belum didasari oleh rencana strategis (renstra) pengembangan pariwisata Jember secara terintegrasi dan komprehensif. Ini ditandai dengan (1) Keterkaitan dan konsistensi antara perencanaan, penganggaran, pelaksanaan pengembangan pariwisata yang mencakup 8 kebutuhan pengembangan pariwisata seperti dijelaskan pada uraian sebelumnya. Contoh, pemasaran pariwisata selama ini lebih banyak ditangani oleh pemerintah Kabupaten Jember; (2) Integrasi, sikronisasi dan sinergi program pengembangan pariwisata (antar instansi daerah, antar fungsi pemerintah daerah). Contoh unit-unit satuan kerja pemerintah yang ada masih menganggap bahwa pengembangan pariwisata merupakan domain Kantor Pariwisata. Padahal untuk mengembangkan pariwisata butuh kerjasama Dinas PU, Bappeda, Dinas Perhubungan, Badan Penanaman Modal Daerah untuk investasi, dan sebagainya.

Kedua, pada aras taktikal,
pengembangan pariwisata Jember
memerlukan koordinasi antar pelaku
pembangunan industry pariwisata dan


penataan kelembagaan (pemda, pelaku bisnis pariwisata, masyarakat) yang dalam FGD masih berkembang pro dan kontra penataan kelembagaan. Realitas ini memberikan implikasi bahwa pengembangan industry pariwisata Jember tidak dapat menyusun rancangan dan implementasi program prioritas pengembangan pariwisata Jember.

Ketiga, pada aras operasional yang fokusnya pada pengembangan sumber daya manusia industry pariwisata dan peningkatan sarana dan prasarana pendukung pariwisata (jalan, hotel, tempattempat kuliner, atraksi, dsb) pada akhirnya menjadi tidak optimal untuk dikembangkan karena pada aras strategi dan taktikal juga masih dijumpai persoalan mendasar. Dengan kata lain apabila renstra dan road map pengembangan pariwisata di Jember belum tersedia atas dasar kebutuhan yang diperlukan dalam pengembangan pariwisata di Jember, maka pengembangan pariwisata di Jember akan tetap bertumpu pada daya pikat pelaksanaan JFC, yang sustainabilitasnya tidak berjangka panjang karena hadirnya kompetitor lain dengan angle yang sama, karnaval fashion.

\section{SIMPULAN}

Melalui model analisis proses jaringan/analytical network process (ANP), pengembangan pariwisata di Jember masih dilakukan dengan pendekatan konvensional, di mana pelaksanaan JFC menjadi ujung tombak daya tarik pariwisata di Jember. Pendekatan konvensional yang meletakkan JFC sebagai factor tunggal pengembangan pariwisata Jember sangat rentan terhadap kesinambungan pariwisata di Jember. Artinya apabila JFC tidak lagi menjadi daya tarik pariwisata Jember, maka penurunan jumlah wisatawan dan efek pengganda (multiplier effect) yang muncul akan mengalami masalah cukup serius. Rekomendasi yang diberikan adalah pengembangan pariwisata di Jember tidak dapat hanya diletakan pada satu event wisata, JFC, tetapi harus dikembangkan jenis dan model pariwisata lain seperti agrowisata perkebunan kopi yang banyak terdapat di Kabupaten Jember.

\section{DAFTAR PUSTAKA}

Budiman, Arief. (1991) Negara dan Pembangunan. Jakarta: Yayasan Padi Kapas.

Burns, S. \& Holden, G. (1995) Tourism, New Perspective. London: PrinticeHall.

Dinas Pariwisata Kabupaten Jember. (2010) Profil Pariwisata Jember. Jember.

Nelson, H. (1993) Tourism and Sustainable Development. Harlow: University of Waterloo Press.

Nugroho, H. (2013) Industrialisasi Sektor Pariwisata, Kelola, UGM Business Review, 16(6), 28-38. 